Niels Jul Nielsen er ph.d. og lektor i etnologi, Saxo-Instituttet, Københavns Universitet. Han har tidligere været museumsinspektør ved Københavns Museum. Han har i en længere årrække beskæftiget sig med industrisamfundets etablering og dets udvikling gennem det 20. århundrede. Hans særlige fokus har været arbejdsliv og arbejdsmarked set såvel $i$ et hverdagsligt mikroperspektiv som $i$ et overordnet, statsligt og internationalt perspektiv. Hovedværker er Virksomhed og arbejderliv. Bånd, brudflader og bevidsthed på B\&W 1850-1920, Museum Tusculanum, 2002, og Mellem storpolitik og værkstedsgulv. Den danske arbejder - før, under og efter Den kolde krig, Museum Tusculanum, 2004.

\title{
ARBEJDEREN MELLEM PRAKSIS OG IDEOLOGISERING 1850-2000
}

Hvad var arbejderklassen? Hvem var arbejderne? Hvorfor var de på alles læber for halvtreds og hundrede år siden, og findes de overhovedet i dag? I artiklen diskuteres brydningerne fra 1850 til 2000 i debatten om arbejdere, deres politiske og ideologiske indflydelse og det konkrete arbejdsliv, de levede. Hvordan så verden ud på værkstedsgulvet? Betragtede man sig som en klasse? Ønskede man at overskride det kapitalistiske samfund? Artiklen veksler mellem at se på arbejderne i deres brogede arbejdsverden og i et overordnet, statsligt, strategisk perspektiv. Hermed fremkommer et komplekst billede af brydninger, modstand og alliancer både arbejdere imellem og i forhold til det øvrige samfund, som artiklen forsøger at forstå i en større, sammenhængende kontekst. På denne baggrund går artiklen også i kritisk dialog med den eksisterende forskning på feltet. 
$\mathrm{I}$ nden for samfunds- og humanvidenskaberne er næppe nogen anden samfundsmæssig gruppe blevet underkastet så mange studier gennem det 20. århundrede som 'arbejdere'. Ja, helt tilbage fra 1800-tallets sidste årtier blev beskæftigelsen med 'arbejderklassen' et af de toneangivende forskningsfelter ikke blot i Danmark, men i størstedelen af den vestlige verden.

Denne interesse er aftaget markant inden for de sidste par årtier. Siden 1990'erne er forskningen drejet i retning af mere personlige vinkler på arbejdsliv såsom performance, stress og karrierehåndtering. Finanskrisen har for så vidt igen skabt et stærkere fokus på bredere arbejdsmarkedsrelaterede spørgsmål - i forbindelse med fx faldende organisering, pressede lønninger og social dumping - men det er karakteristisk, at interessen ikke tænkes i en traditionel 'arbejderklasse'optik, og arbejderspørgsmål spiller i dag en langt mere perifer rolle end tidligere. Jeg vender afslutningsvis tilbage til dette forhold, som står i markant modsætning til situationen gennem det meste af perioden fra omkring 1870 til 1990.

Nærværende artikel har to hovedinteressefelter:

For det første, hvordan man forstod 'arbejderen' i de mere end hundrede år, hvor arbejderspørgsmål stod højt på den politiske dagsorden, og dermed tillige hvilken rolle 'arbejderen' tildeltes og spillede i den samfundsmæssige diskurs?

For det andet, hvordan arbejdernes tilværelse og selvforståelse egentlig forholdt sig til denne rolle: Hvordan var dagligdagen på de store arbejdspladser? Hvordan tænkte man sig i forhold til kollegerne - og til ledelsen? Hvordan kan vi forstå den omfattende opbakning til de formelle faglige organisationer? Som nævnt vender jeg afslutningsvis tilbage til måden, hvorpå man i dag forholder sig til brede sociale og arbejdsmarkedsrelaterede udfordringer og baggrunden herfor.

\section{Et højprofileret forskningsfelt}

Interessen for arbejdere fra 1800-tallets anden halvdel og op gennem det meste af 1900-tallet hang sammen med, at netop denne befolkningsgruppe blev anset for at have en markant samfundsmæssig betydning. Dette var i vidt omfang koblet til en opfattelse af arbejdere som potentielle katalysatorer for en omfattende samfundsforandring. Uden at referere den omfattende litteratur på området ${ }^{1}$ kan man sige, at den grundlæggende begrebsfigur bliver den Marxbaserede opfattelse, at lønarbejdere som underordnede og besiddelsesløse i det kapitalistiske produktionsforhold udgør en klasse 'an sich' (hvilket ikke nødvendigvis indebærer, at de identificerer sig som en klasse 'für sich'). Følgeslutningen af dette forhold bliver gerne, at arbejderne har en 'objektiv' interesse i at afskaffe den kapitalistiske pro-

1 I bogen Virksomhed og arbejderliv (Nielsen 2002) undersøger jeg i kapitlet "Enhed og/eller differentiering - teoretiske indgange til arbejderkultur" de centrale begrebslige figurer i forståelsen af 'arbejderklassen'. 
duktion for profit ${ }^{2}$. Som tidligere DR-direktør, og senere direktør for European Broadcasting Union, Bjørn Erichsen, formulerede det i 1977 i gymnasiebogen Om arbejderbevægelsen: "[Klasse-]kampens mål er en ... kollektivisering af produktionsforholdene... hvor producenterne selv, eller igennem deres demokratisk valgte organer, leder og fordeler deres arbejde". ${ }^{3}$

I citatet fremtræder opfattelsen i 1970'ernes sprogdragt. I senere publikationer udtrykkes opfattelsen af arbejdernes forandringspotentiale på andre måder. I en historisk redegørelse for solidaritetsbegrebet lyder det fx hos Christiansen 1997, s. 13: "Det der binder arbejderne sammen er de to fælles projekter: ønsket om at opnå anerkendelse og visionen om et alternativ til det kapitalistiske samfund". I takt med postmodernismens stigende udbredelse, jf. nedenfor, er den slags udsagn i øvrigt blevet betydeligt færre igennem de sidste årtier som et udtryk for den generelle modvilje mod enhver form for 'grand narrative'. Nærværende artikel fastholder en intention om at kunne pege på overordnede historiske bevægelser, men er samtidig et alternativ til den traditionelle klassekampsanalyse, som ovenstående citater er rundet af.

Historien om arbejderens fremtrædende placering på den samfundsmæssige dagsorden - for nu at ridse baggrunden meget kort op - havde at gøre med, at en kapitalistisk produktionsform baseret på privat ejendomsret, konkurrence og varehandel i løbet af 1800-tallet vandt indpas over store dele af verden i forbindelse med industrialiseringen. Denne produktionsform karakteriseres af et socialt skel mellem dem, der har midlerne til at organisere produktion og tjene penge på markedet, og dem - arbejderne - der udfører (store dele af) det konkrete arbejde og alene tjener deres penge i kraft af den løn, de kan oppebære.

For de iagttagere, samfundsdebattører og forskere, der var bekymret over eller utilfredse med kapitalismens dominans i samfundet - og de var mange - kom det til at betyde, at lønarbejdere over en bred kam blev forbundet med to ting: Dels en særlig kollektivt baseret kultur, udsprunget af arbejdernes underordnede stilling i den økonomiske struktur, hvor de var henvist til at agere i fællesskab for at kunne lægge pres på arbejdsgiverne. Dels - jf. citaterne ovenfor - en besiddelse af et overordnet mål om at overskride det kapitalistiske samfunds grænser og bane vejen for en ny samfundsorden. Dette tildelte arbejdere en nøgleposition i forhold til samfundets udvikling.

I løbet af det 20. århundrede blev det klart, at arbejdere ikke lå inde med et særligt forandringspotentiale, ligesom en udpræget fælles bevidsthed heller ikke var specielt iøjnefaldende. Forskningsmæssigt blev dette i første omgang søgt forklaret inden for en klassisk modernistisk socialhistorisk ramme ved, at man pegede på en lang række eksterne splittende 'faktorer' - så som køn, etnici-

Se eksempelvis leksikon.org, opslag arbejderklassen (besøgt 2012-11-19).

Erichsen 1977, s. 20. 
tet, faglighed ${ }^{4}$ - i forhold til den kerne af enhed, der stadig lå som en immanent begrebsfigur; arbejdere var måske nok en klasse 'an sich', men ikke 'für sich'. I stigende grad inddrog man - med inspiration fra antropologi og mikrohistorie - også mindre håndfaste størrelser såsom forskellige 'livsstile' og mentaliteter blandt arbejdere, således at man også talte om et skel mellem fx egensindige og 'skötsamme' (respektable) arbejderes; alt sammen for at få forklaret den åbenlyse kompleksitet, som arbejderkulturen var præget af. Principielt fastholdtes opfattelsen af, at det gav mening at tale om arbejdere som en specifik kulturel kategori, der blot kæmpede mod en - i princippet uendelig - række af splittelseskilder, som var ydre i forhold til kulturens kerne.

Med postmodernismens stigende betydning syntes det nærliggende næste skridt at blive taget. Her blev peget på, at arbejdere næppe nogensinde havde identificeret sig over en bred kam med begreber som klasse og solidaritet, ligesom en fastholden af, at der skulle være tale om en særlig lønarbejderkultur (eller '-klasse') mere og mere betragtedes som et hult postulat. Således konkluderede fx den engelske historiker Patrick Joyce i en undersøgelse af brugen af 'klasse' i (samtids)litteraturen om arbejdere i midten af 1800-tallet: "Other forms of the self and of collective identity emerge, long obscured by the concentration on class." 6 Eller sagt med andre ord: Det er en misforståelse at tildele 'klasse' en privilegeret plads som indgang til og forklaring på arbejderes selvforståelse og kultur.

Opgøret med firskårne påstande om eksistensen af en særlig arbejdermentalitet er både nødvendig og forståelig; arbejdere tænker sig ikke nødvendigvis inden for en større og bredere arbejdermæssig enhed. Men i kølvandet på opbruddet kan man samtidig passende spørge: Hvis arbejdere forstås bedre med begreber. som peger på helt almenmenneskelige karakteristika, hvorfor så egentlig tale om dem som andet end individer?

Det kulturelt heterogene billede af arbejdere er således ikke til at komme uden om. Men at takle denne kompleksitet ved blot at applicere stadig flere etiketter på empirien - eller helt opløse begrebet - risikerer at gøre os blinde over for væsentlige træk i den kulturhistoriske udvikling. Når 'arbejdere' (hvordan vi så end skal forstå dem) notorisk har spillet en afgørende, dagsordensættende rolle i store dele af det 20. århundrede, forekommer det ikke sandsynligt, at der ikke skulle knytte sig nogle særlige - fælles - karakteristika til dem. Men samtidig må det være udfordringen at kunne forholde sig til, at der er en uomgængelig diversitet

4 Man tog her fat i grænseskabende forhold, der havde været erkendt gennem hele arbejderbevægelsens historie. Fx pegede allerede Engels og senere Lenin på tilstedeværelsen af et såkaldt labour aristocracy, der i forsøget på at fastholde privilegier på bekostning af andre ikke udviste solidaritet med andre arbejdere, jf. også Goldthorpe 1969 og Gray 1976.

5 Se fx Lüdtke 1986 og Horgby 1993.

6 Se fx Joyce 1991 og Jones 1983. 
på færde, vel at mærke uden at denne skal finde sin begrundelse i eksterne splittelsesfaktorer.

\section{Det nære studies nødvendighed}

En måde at komme videre på er at se på, i hvilke sammenhænge henholdsvis enheden og differentieringen har åbenbaret sig. Og her kan det være formålstjenligt at tage det nære empiriske studie til hjælp. Vi må forstå, hvad der egentlig var på færde mellem disse mennesker gennem de godt hundrede år fra slutningen af 1800-tallet og frem. Ved at kombinere en sådan mikrotilgang med de overordnede nationale og internationale udviklingstræk skal det i det følgende forsøges at give en karakteristik af en kompleks kulturel størrelse fra det, man kunne kalde dens fødsel, over dens konsolidering og stigende storpolitiske betydning til det, der i dag ligner dens opløsning.

Det følgende baserer sig på tyve års studier af arbejderkultur fra midten af 1800-tallet til i dag, forstået bredt som dels dagligdagens arbejdsliv på værkstedsgulvet, ${ }^{7}$ dels den bevægelses- og organisationsbaserede dimension i det, der er blevet kaldt 'arbejderklassen'. Min metodiske tilgang har bestået i indefra/nedefra - at kombinere tætte og nære analyser fra individuelle sammenhænge ved at 'rekonstruere' arbejdsliv og dagligdag på konkrete arbejdspladser med - oppefra/udefra - at udforske initiativer og rationaler fra organisatoriske og politiske sammenhænge. En sådan approach er almindelig i etnologiske kredse, men har her været særligt inspireret af den strukturelle stats- og livsformsanalyses skelnen mellem samfund og stat.

Sagt enkelt: Samfundet ses som sæde for brydningen mellem divergerende interesser (livsformer/klasser), staten som sæde for en almen vilje betinget af såvel indre samfundsmæssige brydninger som ydre storpolitiske udfordringer - og imellem de to 'niveauer' et komplekst spil af krav/modstand og interpellation/ anerkendelse. ${ }^{8}$ Med denne fremgangsmåde har det været hensigten at opnå størst mulig empirisk følsomhed og nuancerigdom og samtidig bevare blikket for, hvilket dagligliv og handlemønstre der overhovedet er levedygtige og kan praktiseres - og hermed også, hvordan der i den kulturhistoriske udviklingsproces forekommer afgørende forandringer heri.

Endnu en fordelagtig konsekvens af en skridtvis rekonstruktion af hverdagspraksis baseret på en meget bred kildemæssig tilgang er, at man (i dele af analy-

7 Familie- og fritidsliv har spillet en mindre rolle i undersøgelserne, hvilket er en - beklagelig, men uomgængelig - følge af det metodiske valg om at skabe en stabil ramme baseret på konkrete virksomheder.

8 For en nærmere gennemgang af de principielle teoretiske og metodiske tankegange i den strukturelle stats- og livsformsanalyse, se fx Højrup 1996. 
sen) kan gøre sig uafhængig af diskursivt ladet materiale (fx avis- og andet debatstof), skabt i samtidens meningsbrydninger og præget af normative udsagn om de involverede aktørers indstilling til forholdene. Den form for materiale er naturligvis centralt også i en forståelse af udviklingen og den samfundsmæssige positionering af lønarbejdere, men man kan faktisk først for alvor bringe det kvalificeret i spil, når det kan sættes i forhold til de mange aspekter af arbejdernes praksis, der foregår helt anonymt dag ud og dag ind - og som ofte blotlægger helt andre kulturelle træk end dem, der betones i de udadvendte meningsbrydninger.

For at komme tæt på hverdagspraksis og kulturel orientering blandt dem, der gennem mere end et århundrede er blevet identificeret som 'arbejdere', er det således ikke tilstrækkeligt at se på diskurs og mere overordnede udviklingstræk som partidannelse, organisationsdannelse og politisk betydning. Man skal også have indsigt i de dagligdags handlemønstre på individuelt niveau, hvor aktører står over for hinanden og forholder sig til de omstændigheder, de bydes i en given historisk kontekst. For at have mulighed for dette sidste er det nødvendigt at etablere et afgrænset felt, hvor ageren og forholdemåder kan undersøges i detaljer over store tidsmæssige spænd samtidig med, at de på en meningsfuld måde er sammenlignelige.

Til det formål benyttes her et detailstudie af Danmarks største virksomhed gennem tiderne, Burmeister \& Wain. Denne arbejdsplads har i nærværende sammenhæng ydermere det fortrin, at den uden sammenligning er landets mest italesatte virksomhed netop i relation til den politisk/ideologisk dagsorden om lønarbejdere som eksponenter for kollektiv ageren og samfundsomvæltning. Ydermere er der tale om en virksomhed, der har gjort hele turen med fra den helt tidlige industrialiseringsfase før midten af 1800-tallet frem til i dag, hvor den - i stærkt ændret form - eksisterer med en i hovedsagen til Fjernøsten outsourcet produktion. Det følgende bygger på eksempelmateriale, udredninger og forskningsresultater i bøgerne Virksomhed og arbejderliv. Bånd, brudflader og bevidsthed på B\&W 1850-1920 samt Mellem storpolitik og værkstedsgulv. Den danske arbejder før, under og efter Den kolde krig. ${ }^{9}$ Hvad angår det materialemæssige grundlag over de halvandet hundrede år, siger det sig selv, at det er såvel omfattende som stærkt varierende, og det fører for vidt her at redegøre for det i detaljer. I forbindelse med de eksempler, der nævnes i det følgende, peges der på de benyttede kilder.

\section{Etablering af en samfundsmæssig gruppe}

I september 1871 danner B\&W skibsværft på Christianshavn ramme om danmarkshistoriens første store strejke i perioden efter håndværkerlavenes afvikling

9 Nielsen 2002 og 2004. 


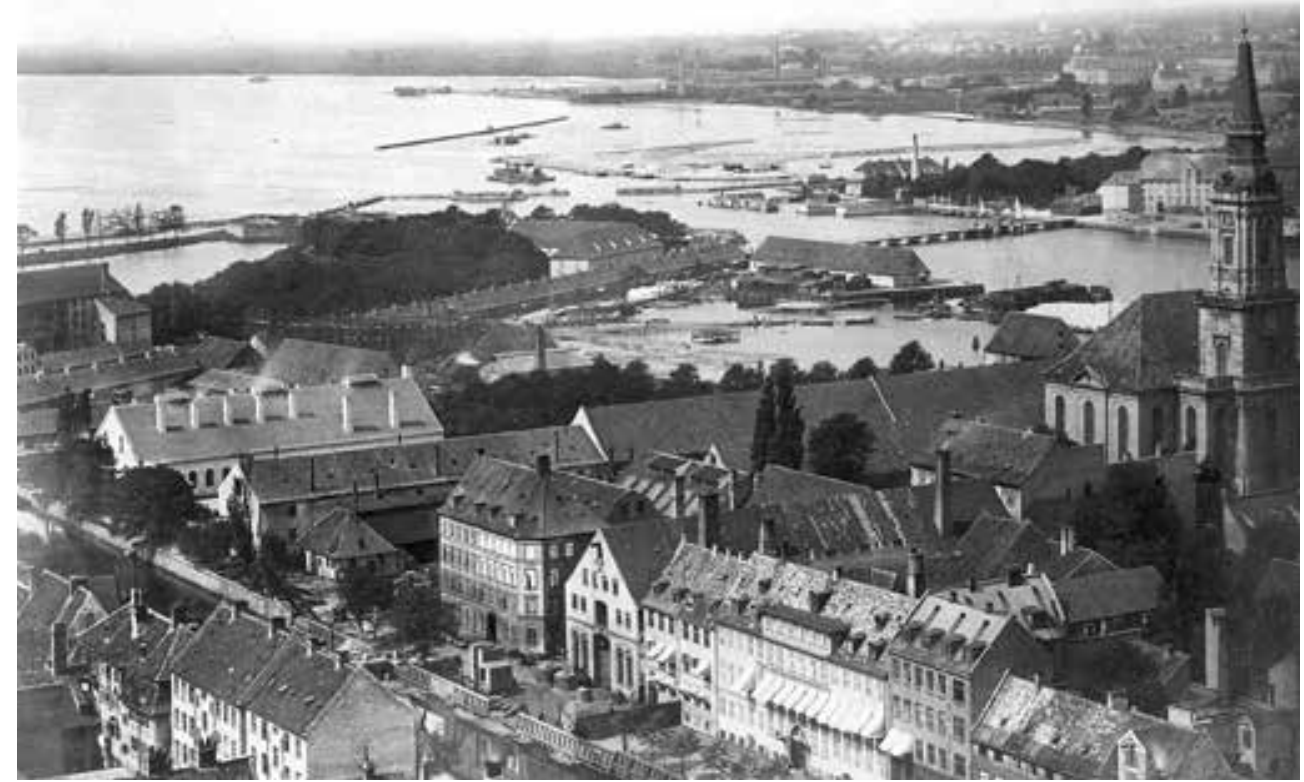

Udsigt over Burmeister \& Wains anlæg på Christianshavn i 1871 fra tårnet af Vor Frelser Kirke. I forgrunden ses kedelsmedje (med gavlen ud mod kanalen), maskinværksteder og støberi (op mod Christianskirken) og grovsmedje (med de mange hvide skorstene fra esserne). I baggrunden anes skibsværftet; et skibsskrog på bedding rager op over hustagene lidt til venstre for midten. Det er netop i forbindelse med, at en nybygning skal løbe af stablen, at den store konflikt i 1871 bryder ud og for alvor sætter 'arbejderspørgsmålet' på den offentlige dagsorden i Danmark. Fotografiet er dog taget i foråret under helt andre omstændigheder, nemlig i forbindelse med Burmeisters 25-års jubilæum som fabriksejer på Christianshavn. Et kvart århundrede er på det tidspunkt hengået, uden at 'arbejdere' er blevet forbundet med den potentielle trussel, som bliver kendetegnende for de følgende mere end hundrede år. Foto: B\&W, MAN Diesel.

ved Næringsloven af 1857 (effektueret fem år efter). Omtrent 300 arbejdere nedlægger arbejdet efter, at nogle kvartermænd - arbejdsledere - har undladt at efterleve den sædvane, at man holder resten af dagen fri, når en nybygning er løbet af stablen. Strejken finder sted i en periode hvor der allerede er røre i både ind- og udland: I løbet af foråret og sommeren har den københavnske offentlighed med gru - bl.a. via dusinvis af detaljerede xylografier i månedsmagasinet Illustreret Tidende - fulgt med i tildragelserne i Frankrigs hovedstad, hvor fattige arbejdere i socialismens navn har indført Pariserkommunen, et regime, der senere nedkæmpes af franske tropper. Herhjemme har der i samme periode været arbejdet på at skabe en dansk afdeling under den af Marx i 1864 i London stiftede Internationale med en erklæret grænseoverskridende målsætning om at etablere en solidaritet blandt alverdens arbejdere som et middel til at frigøre sig fra kapitalens tvang. Arbejdskonflikten på B\&W bliver af de socialistiske ledere i Danmark brugt 
som anledning til at indkalde til et stormøde, og et par uger efter konstitueres den danske afdeling af Internationale. ${ }^{10}$

Der er med disse begivenheder umiskendeligt tale om en begyndende kollektiv bevidstgørelse blandt arbejdere. De erfarer, at de ved at organisere sig og samle deres kræfter til én stemme kan opnå indflydelse. Også for samfundet i øvrigt er der tale om en erkendelsesproces. De fleste ved godt, at den pågældende konflikt ikke blot er et vildskud på en ellers sund og levedygtig vækst. Kapitalismens indtog har bragt samfundet i ubalance og den nye bekymring bliver snart kendt som 'arbejderspørgsmålet'.

I løbet af de følgende tre årtier bliver - med meget store lokale variationer - den danske arbejder integreret i en kollektiv bevægelse mod anerkendelse og repræsentation. En bevægelse, der i store træk er international, dog få steder i så rendyrket formaliseret form som i Danmark, hvor Septemberforliget i 1899 knæsætter arbejdere og arbejdsgiveres gensidige anerkendelse af modpartens organisationsret.

\section{En broget mangfoldighed}

Men hvad er denne bevægelse mod enhedsdannelse og fælles ageren egentlig udtryk for? Lad os vende blikket mod tilstandene bag fabriksporten for at få et kendskab til, hvordan verden ser ud bag de formaliserede og udadvendte sammenhænge. B\&W producerede i 1800-tallets anden halvdel dels arbejdsmaskiner til industrien, først og fremmest kraftmaskiner, dels skibe. Det sidste foregik indtil starten af 1870'erne på Christianshavn tæt på den øvrige produktion, og herefter - helt frem til værftslukningen i 1996 - på et nyanlagt værft på Refshaleøen i den nordlige ende af Københavns havn.

Det er naturligvis ikke uproblematisk at nærme sig den daglige livssammenhæng på en arbejdsplads i en periode, hvor man ikke har adgang til mundtlige beretninger. Min fremgangsmåde har bestået i videst muligt omfang at 'rekonstruere' (vel vidende at noget sådant uvilkårligt rummer en god del 'konstruktion') en række af de træk, der knytter sig til selve produktionen og arbejdernes involvering i denne ${ }^{11}$ : Hvad er det, der fremstilles? Hvordan gøres det? Hvem gør det? Hvilke kompetencer er nødvendige? Hvilke samarbejdsrelationer udfolder sig? Hvilke niveauer af arbejdsledelse er involveret? Og desuden: Inden for hvilke in-

10 Konflikten er behandlet $\mathrm{i}$ samtiden af en stort set overensstemmende dagspresse - her er især benyttet Arbeideren nov. 1871, Socialisten nr. 111871 (september), 2.10.71, 7.10.71, 14.10.71, 21.10.71 og Berlingske Tidende 2.10.71. Den omtales endvidere detaljeret i Lorentzen og Kjærbøl 1925, 18ff.

11 Det er en meget bred vifte af upubliceret kildemateriale fra virksomhedens eget arkiv foruden samtidige håndbøger i 'mekanisk teknologi', erindringsmateriale, mv. der er brugt til at skabe denne indsigt. I Nielsen 2002 redegøres der løbende gennem bogens analyser for kildegrundlaget, der skifter markant gennem de syv årtier fra 1850 til 1920 som undersøgelserne i denne bog dækker. 
den- og udendørs rum har aktiviteterne fundet sted? Hvor foregik hvilket arbejde? Hvor kunne man holde pauser, formelle såvel som uformelle?

Et kig ind i værksteder og rundt på de udendørs arbejdspladser giver først og fremmest et billede af en kolossal mangfoldighed. Der er næsten ikke det faglige håndværk, der ikke er repræsenteret - her er grov-, kobber-, kedel-, skibs- og klejnsmede, formere og modelsnedkere (der udfører træmodeller af emner, der skal støbes), maskinarbejdere, tømrere, arbejdsmænd osv. Og de er fordelt på et utal af små og store værksteder, på udendørs byggebeddinger og store produktionshaller. Når man gennem arbejdsjournaler ${ }^{12}$ og andet arkivmateriale ${ }^{13}$ analyserer, hvordan arbejdsprocesserne rent faktisk er foregået, bliver mangfoldigheden kun forstærket. Der er ikke grænser for, hvilke arbejdsoperationer der udføres, nogle fagligt krævende, andre nærmest rutinearbejde, nogle steder med mange niveauer af arbejdsledelse, andre steder næsten uden. Men hvordan ser arbejderne hinanden, føler de sig som et kollektiv i disse mere uformelle dagligdags sammenhænge? Og sker der markante ændringer i årtierne efter 1870 parallelt med konsolideringen af arbejderbevægelsen?

Et mål for arbejdernes indbyrdes relationer er lønnen, som de jo i fællesskab skal dele af virksomhedens samlede lønpulje. Men det er i nærværende sammenhæng en væsentlig pointe, at se lønmønstret som et udtryk for mere generelle arbejdsforhold, der blot viser sig mere sporadisk i kilderne, er mindre håndgribelige og svære at måle og sammenligne. Jeg tænker her på betydningsfulde forhold såsom graden af belastning og nedslidning ved arbejdsopgaverne, muligheden for at holde pauser, råderummet i forhold til undermestre og mestre, indflydelsen på at få lukrative arbejdsopgaver, udsigten til at have stabil tilknytning til virksomheden gennem hele tilværelsen, chancen for at få sin søn ind som lærling og

12 Arbejdsjournaler er ikke en standardiseret form for dokumentation og dermed heller ikke en kildetype, der er almindelig på danske arbejdspladser; i hvert fald er de kun i få tilfælde bevaret. På B\&W består de som hovedregel i mesterens daglige relativt sporadiske opgørelse over dels arbejdet, der er udført og dels de personer (benævnt ved efternavn), der har udført det; over hvor mange timer og til hvilken løn. De er ikke ensartet ført og er i øvrigt kun bevaret i nogle perioder i 1800-tallets anden halvdel og langt fra dækkende for de forskellige værksteders brede virkefelt. Da de imidlertid for et konkret stykke arbejdes vedkommende viser kompleksiteten i opgaver og aflønning er de velegnede til nærværende formål.

13 Her har bl.a. kortmateriale givet værdifuld indsigt i værkstedsindretning, løbende ombygninger og tilpasninger, ligesom inventarlister har bidraget til den skridtvise rekonstruktion. Erindringsmateriale (fra senere perioder) omkring arbejdsprocesser og arbejdstilrettelægning har kunnet benyttes, når der efter al sandsynlighed ikke er sket afgørende forandringer på disse områder. 
meget mere. ${ }^{14}$ Mulighederne for indflydelse på så betydelige aspekter ved arbejdet kan ses som parallel til det lønmønster, der kan konstateres. Lad os altså have dette i baghovedet, når vi i det følgende ser på, hvordan lønnen tildeles.

Man kan glemme alt om, at den tidlige industrialisering gennem 1800-tallets sidste halvdel på arbejdersiden dannede ramme om en nogenlunde egal løntildeling - der så senere måtte vige for en individualisering, som vi gerne knytter til det senmoderne samfund. Lønforskellene på værkstederne er simpelthen eksorbitante. For de faglærte svende - oven i købet inden for samme værksted - er forskelle i timelønnen på $30 \%$ helt almindelige. ${ }^{15}$ De lavest lønnede er stort set på niveau med de ufaglærte arbejdsmænd. Hertil kommer et meget udbredt system af forskellige former for akkorder, der giver mulighed for en langt videre differentiering og som tildeles højst forskelligt.

I nærværende sammenhæng er det væsentligt, om dette mønster undergår en principiel forandring med fagforeningsdannelserne og den større formalisering af arbejdsmarkedsforholdene i årtierne efter 1870. Det kan tørt konstateres, at det gør det ikke. Tværtimod synes en væsentlig bevæggrund til at støtte op om organisationsdannelsen i 1800-tallets sidste årtier at være en fastholdelse af dette system - naturligvis nu med en øget mulighed for på et generelt plan at løfte niveauet. Der hæges om den interne differentiering og den konsolideres endda, bl.a. ved at de faglærte folk bruger deres styrke til at lægge afstand til arbejdsmændene. Det sker bl.a. gennem de stadig flere værkstedsklubber, som arbejderne opretter som lokale forhandlingsorganer organiseret under de nye fagforeninger. Og mønstret genfindes endvidere i en række 'reproduktive' foreninger - sygekasser, understøttelsesforeninger, selskabelige foreninger - der i vidt omfang oprettes i regi af de adskilte værksteder og fag. ${ }^{16}$ Ja, også en stor del af det sociale samvær i marketenderi, og når der holdes reglementerede og ureglementerede pauser osv., synes - i det omfang vi kan få kendskab til det - at foregå inden for de samme rammer.

14 Et kendskab til forhold som disse er først og fremmest opnået gennem 29 erindringer blandt Nationalmuseets Industri-, Håndværker og Arbejdererindringer, der er ført omkring 1950 typisk af aldrende arbejdere, og derfor beskriver forhold fra 1880'erne og frem. Også visse jubilæumsværker, især Lorentzen og Kjærbøl 1925, rummer værdifulde oplysninger herom. Avismateriale giver også i nogle tilfælde indblik i hverdagslige forhold på arbejdspladserne. Samtlige avisartikler indeholdende oplysninger fra B\&W fra Socialisten/Social-Demokraten, Politiken og Berlingske Tidende for perioden ca. 1870-1910 (fremfundet via det kartotek, der blev udarbejdet i 1920'erne i regi af Institutet for Historie og Samfundsøkonomi) er benyttet. For perioden efter 1880 'erne begynder protokoller fra værkstedsklubber og vedtægter fra samme at kunne bruges til samme formål.

15 I forbindelse med etableringen af en alderdomsforsørgelseskasse på B\&W udarbejdes årligt i perioden 1874-1897 en liste over samtlige medlemmers løn og ansættelsessted i virksomheden samt deres personlige data (fødselsår, ægteskabelig stand m.m.). Med denne kilde har det været muligt at se den individuelle - differentiede - løntildeling på værkstedsniveau (og naturligvis også på virksomhedsniveau) såvel synkront som diakront.

16 Et kendskab til disse skyldes først og fremmest en meget rig samling af småtryk på Det Kgl. Bibliotek fra netop B\&W; denne rummer i øvrigt også virksomhedssange og festprogrammer fra 1850 'erne og frem. 
For at vende tilbage til lønnen som ét mål for differentieringen, er det ganske sigende, at forskningen ikke har været opmærksom på - eller interesseret sig for den udtalte diversitet. Den ubestridte autoritet på området, Jørgen Pedersen, der i 1930 kortlagde arbejdslønnens udvikling i Danmark, springer stort set over området. Han nævner kort, at lønforskelle nok skal henføres til "det ret mekaniske Anciennitetsprincip”, ${ }^{17}$ altså at eventuelle lønstigninger følger med længere ansættelse. Konklusionen er aldeles misvisende. Der er ingen generel sammenhæng mellem løndannelse og anciennitet ${ }^{18}$ - Pedersen er simpelthen slet ikke gået ind i problematikken omkring løndifferentiering. Som så mange andre anser han en sådan for underordnet i forhold til en generel bevægelse mod stigende lønninger fremtvunget af et stadig mere effektivt kollektivt pres. Hovedpointen her er imidlertid, at differentieringen (også) på lønområdet (frem for at skulle anskues som en uvæsentlig afvigelse fra bevægelsen mod større samling) skal ses som en helt integreret del af den nye livsmåde.

Der er med andre ord to - tilsyneladende modsatrettede - træk, der knytter sig til tilblivelsen af den nye befolkningsgruppe arbejdere. På den ene side sker der en bevidstgørelse af arbejderne som en gruppe, parallelt med at de organisatorisk gennemgår en samling, hvor de gennem formaliserede instanser får etableret virkemidler til at opnå indflydelse på deres løn- og arbejdsforhold (i bredere forstand forudsætningen for deres livsforhold). På den anden side er de karakteriseret ved en markant indre grænsedragning, der ikke blot fastholdes, men konsolideres parallelt med den organisatoriske samling og ensartning.

\section{Sameksistens af enhed og forskelle}

Når enhedsdannelsen og differentieringen så udpræget sætter sig igennem på samme tid, er det ikke tilfredsstillende at skulle fortolke differentieringen som en afvigelse fra en indre kerne af enhed, hvor differentieringen forstås som en slags uforløsthed i forhold til et grundlæggende princip om solidaritet - en 'an sich', der endnu ikke er blevet en 'für sich'. En sådan anskuelse gør sig eksempelvis gældende i et udsagn som det følgende, der fint repræsenterer en almindelig udbredt opfattelse af den manglende overensstemmelse mellem en begrebslig forståelse af arbejdere og deres historisk-empiriske udfoldelse:

Arbejdersolidariteten er horisontal... en klassesolidaritet, der overskrider grænser... den overskrider lavenes sektorale, uddannelsesmæssige og fagbestemte 


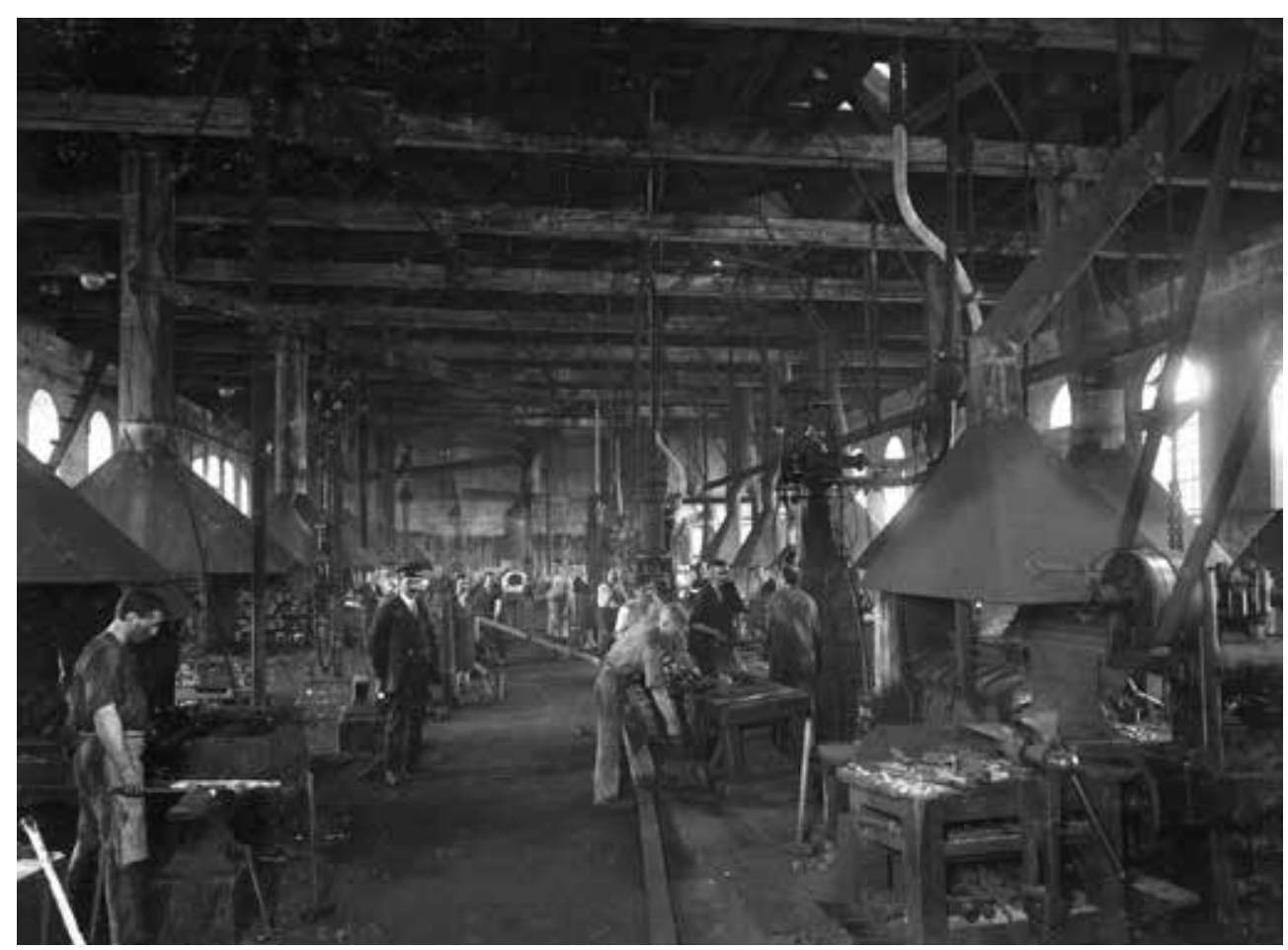

Den kontinuerlige indbyrdes konkurrence arbejdere imellem om udbyttet af deres ansættelse giver en sag fra Refshaleøens grovsmedje i 1909 et godt billede af. Grovsmedjen har en hovedopdeling på smedere og hjælpere, med smederne som dem, der styrer processen. Gennem en årrække er der opstået en stadig større lønforskel mellem de to grupper, og i 1909 forsøger hjælperne derfor at få smederne til at afstå fra lønstigninger "undtagen at Vedkommendes Hjælper ligeledes får sin Timeløn forhøiet med samme antal Øre". Det nægter smederne og henviser til klublovene, der forpligter hver enkelt til "at hæve sin Løn og Arbejdsvilkaar så høit som muligt". Efter mange og gentagnediskussioner, bl.a. med inddragelse af forbundsformanden, får smederne medhold for ikke at "stagnere Lønudviklingen". Få år efter opnår hjælperne så selv en betydelig lønstigning, uden at smederne følger med. Sagen eksemplificerer i miniformat, hvordan mindre eksklusive arbejdergrupper har bedre muligheder for at forbedre deres løn (og diverse andre arbejdsvilkår), hvis de står alene. Samtidig er hjælpere og smedere forbundne som en enhed af lønarbejdere i mere overordnede fagpolitiske sammenhænge, hvor anerkendelse af forhandlingsret og grundlæggende vilkår lægges fast. Også forholdet til mesteren - der her ses til venstre for midten - er flertydigt; på den ene side repræsenterer han ledelsen, på den anden side er han garant for at bestemte arbejdere har adgang til fastsatte arbejdsområder. Billedet er fra 1919. Foto: B\&W, MAN Diesel

sammenhold. At denne overskridelse, som vi ved, i nogen udstrækning forbliver et ideal, rokker for så vidt ikke ved princippet. ${ }^{19}$

Hvis det er rigtigt, at såvel enhedstrækkene som differentieringen er centrale og vedvarende - dele af arbejdernes praksis gennem historien, synes en sådan konklusion ikke at være tilfredsstillende. Så må udfordringen i stedet bestå i at 
redegøre for de sammenhænge eller det princip, der kan forklare denne vedvarende sameksistens af enhed og differentiering. Her har den strukturelle stats- og livsformsanalyse et bud. I denne teori er lønarbejderen - som en begrebsligt konstrueret livsform - bestemt i et gensidigt betingelsesforhold til den kapitalistiske produktion: Ligesom den kapitalistiske virksomhed kræver folk, der kan levere nyudvikling og innovation for at kunne klare sig på markedet, fordrer den en større eller mindre bestanddel af arbejdere, der udfører allerede definerede arbejdsopgaver (som kan være såvel simple som kundskabskrævende). Det, som lønarbejderen henter på den kapitalistiske produktionsenhed, er de nødvendige forudsætninger for at kunne 'reproducere' sig selv - heraf den biologiske term, livsform. Virksomheden bliver således en uomgængelig bestanddel i lønarbejderens liv. For at få indflydelse på reproduktionens konkrete niveau er det nødvendigt at kunne lægge pres på virksomheden ved at monopolisere sit arbejde, så det ikke bare overtages af andre, der er villige til at arbejde på ringere betingelser. Arbejde er som bekendt i den kapitalistiske produktionsmåde en vare, men gennem monopolisering af arbejdsudbuddet sættes konkurrencen på denne vare (i midlertidige konstellationer) ud af kraft. Her har vi forklaringen - som den da også generelt fremføres - på organisationsdannelsen og den kollektive optræden.

Denne udgave af monopolbegrebet er meningsfuld, når man ser den i forhold til en samlet enhed af kapital. Men i den form optræder kapitalismen kun for en helt almen betragtning. For at kunne forstå den måde, hvorpå kapitalismen realiseres i verden, må man specificere til næste trin, hvor det er den indbyrdes konkurrence mellem kapitaler, der er i fokus. I praksis møder arbejderne nemlig kapitalismen i form af en uendelig række af konkurrerende enkeltkapitaler - der dermed også konkurrerer om arbejdskraften. Det betyder, at prisen på arbejde er forskellig. I den situation er monopoliseringen ikke et hensigtsmæssigt middel i en form, hvor den inkluderer samtlige verdens arbejdere ${ }^{20}$. Monopoliseringen bliver derimod et effektivt middel i skabelsen af bedre livsbetingelser, hvis man kan fremstå i forhold til arbejdsgiveren som en mindre gruppe - altså et afgrænset monopol. Eksemplificerer man med arbejderne på B\&W, betyder det, at det er langt nemmere for fx svendene i grovsmedjen i en gunstig forhandlingssituation, hvor de ved, at deres kompetencer er efterspurgte, at få forbedret deres løn (samt diverse andre arbejdsvilkår), hvis de ikke samtidig repræsenterer B\&Ws tømrere, snedkere, nittere, stemmere, ufaglærte arbejdsmænd; for ikke at sige resten af landets, eller for den sags skyld verdens, arbejdere. Ja, for at presset skal føre til resultater, bliver de simpelthen nødt til at fremstå som eksklusiv gruppe. I en anden sammenhæng vil det være de ufaglærte eller nogen af de andre faggrupper, der gør det. Hvilket på et lidt større plan er det, der viser sig i fagbevægelsens

20 Man kunne hertil tilføje, at et alle-inkluderende lønpres ville udgøre så markant en trussel for kapitalismens egen reproduktion, at alle midler formentlig ville blive sat ind for at forhindre det. 
udspaltning i en myriade af fagligheder, der hver for sig har forhandlingsret til prisen på specificerede og afgrænsede arbejdsområder.

Monopoliseringsbegrebet har således både en inkluderende og en ekskluderende side. Den inkluderende side kan omfatte alle i den forstand, at alle skal anerkende spillets regler om, at man indgår i et system af bindende relationer mellem arbejdere og arbejdsgivere, at man anerkender grænsedragninger mellem fagligheder og arbejdsområder (og dermed også alt fra hovedorganisation, fagforbund, fagforeninger til lokale virksomhedsklubber) samt at man overholder indgåede aftaler; om dette så realiseres i et meget formaliseret system som det danske med en høj organisationsprocent eller i mere uformelle former, hvor overholdelse af aftaler snarere hviler på personlige relationer er ikke afgørende. Den ekskluderende side kan slet ikke tænkes uden denne overholdelse af spillets regler, men er til gengæld helt uomgængelig, hvis arbejdergrupper i konkrete forhandlingssammenhænge skal have indflydelse på deres løn og arbejdsvilkår og dermed i dybere forstand for betingelserne for at leve et liv som lønarbejder. Eksklusive monopoler er på ingen måde givne. Der foregår en konstant kamp om anerkendelse af dem og ikke mindst om de grænser i forhold til andre, der er helt afgørende for at kunne fremstå som veldefineret part i forhandlinger, og for at opnåede rettigheder efterfølgende bliver overholdt. De eksklusive monopoler skal anerkendes af ikke blot arbejdsgiversiden, men også af andre arbejdere, således at alle hver især respekterer hinandens afgrænsede arbejdsområder.

Med disse udredninger giver det mening med den vedvarende modsætningsfuldhed, som det historiske studie blotlægger. Afhængigt af hvad der er forhandlingspolitisk opportunt på et givent tidspunkt, kan det i én periode, i én sammenhæng, være fagligheden, der føres i felten i forhandlinger med modparten. I andre kan det være kønnet, attituden (fx om man er en tilregnelig, 'skötsam', arbejder) eller, ja, ancienniteten. Men pointen er, at disse karakteristika ikke skal ses som udtryk for en endnu ikke fuldendt udradering af differentieringskilder. Tværtimod. De grænseskabende karakteristika må (frem for blot at blive set som almindelige menneskelige træk) ses som integrerede i en lønarbejderpraksis, i den nødvendige kamp for at sikre indflydelse på reproduktionsvilkårene. Med andre ord: Havde det ikke været det ene eksklusionskriterium, der gjorde sig gældende, ville det have været et andet.

Der er ikke i sig selv noget nyt i at pege på en udpræget indre differentiering i arbejderbefolkningen. Allerede Marx rettede fokus på den oven for skitserede sammenhæng mellem kapital og arbejderside som den realiseredes empirisk og formulerede det bl.a. på følgende måde: ”Arbejdernes indbyrdes konkurrence er blot en anden form for kapitalernes konkurrence". ${ }^{21}$ 


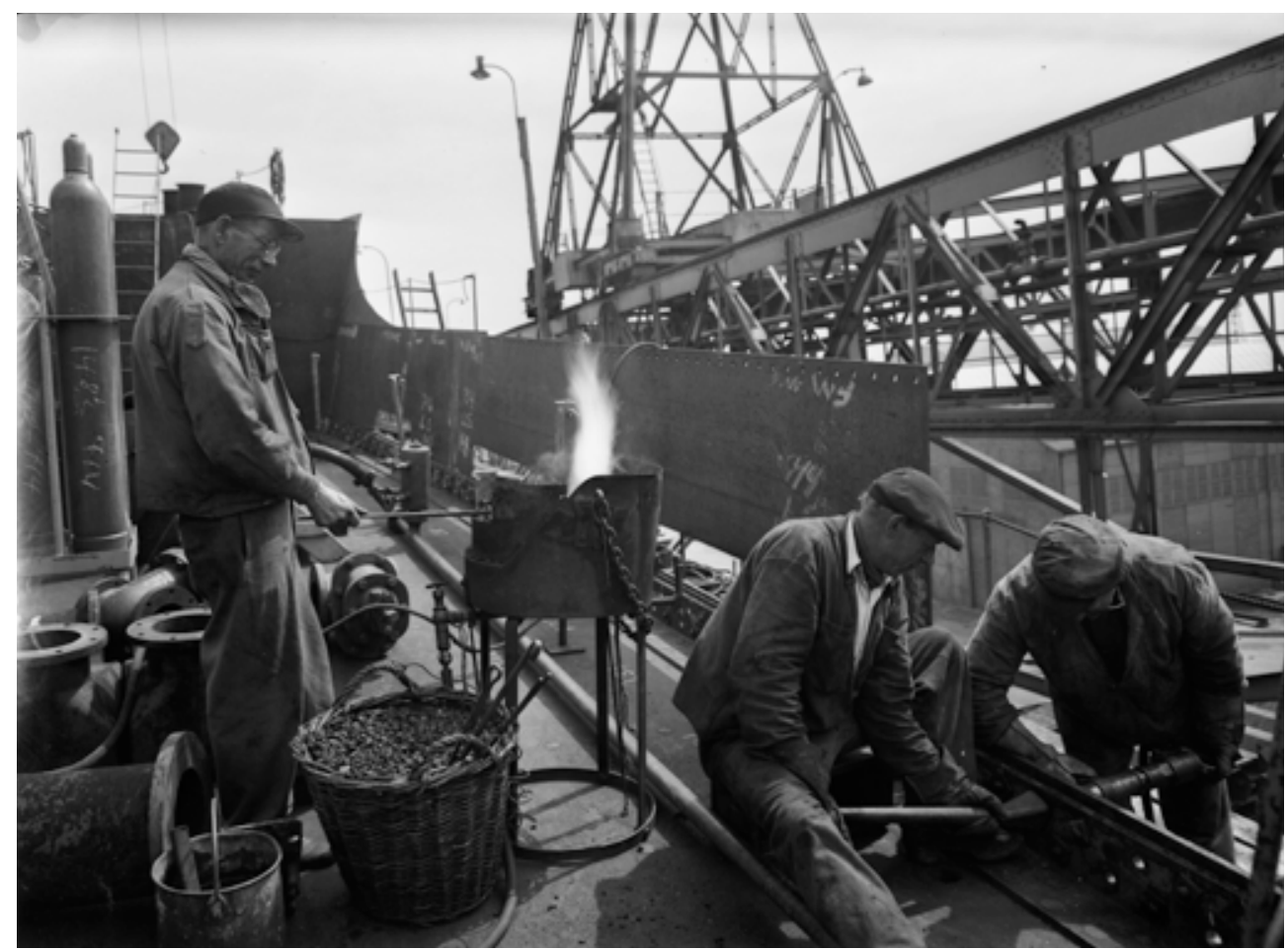

Billede fra 1950'erne af et nittersjak i den periode, hvor man stadig ikke er gået over til i alle tilfælde at benytte svejsning, når stålplader skal samles. Naglevarmeren gør nitnaglerne rødglødende i den mobile esse, nitteren bearbejder naglen med den pneumatiske hammer, forholderen holder imod på den modsatte side af samlingen. Er adgangsforholdene vanskelige, hvilket ofte er tilfældet på et skib, inkluderer sjakket tillige en naglelanger. For at gøre samlingen tæt skal kanterne efterfølgende mejsles jævn af en stemmer. At være 'nitter og stemmer' var kategoriseret som en almindelig håndværksuddannelse trods det, at selve arbejdsfeltet var meget begrænset og ikke voldsomt kundskabskrævende - selv om en gammel B\&W-arbejder nok overdrev lidt, da han i 1996 fortalte, at det kunne læres på en eftermiddag. Oprindelig foregik nitning ved håndkraft ved, at to nittere på skift svang en speciel nittehammer; det skulle foregå med præcision og gå hurtigt, så naglen blev bearbejdet, mens den var varm. At fagområdet også efter indførslen af luftværktøj fortsat havde status af faglært håndværk, er et udtryk for, at fagområder og faggrænser snarere handler om fagpolitisk styrke og position end om håndværksmæssigt indhold. Foto: B\&W, MAN Diesel

Forståelsen af disse brydninger får imidlertid i et livformsperspektiv en grundlæggende anden drejning end i en traditionel klassebegrebsanalyse. Klasseanalysen anser en samling af arbejdere omkring en klassebevidsthed og en afvikling af den kapitalistiske produktionsmåde som to sider af samme sag. Det indebærer, at den vedvarende differentiering - uanset den måtte foregå parallelt med en opbakning til også monopoliseringens inkluderende side - bliver at betragte som et misforhold med udspring uden for 'klassens' fælles bestemmelse, en betragtning, der har bidraget med et syn på arbejderbefolkningen i sin historiske realisering som en noget uforløst kulturel formation, i de mest radikale udlægninger som en gruppe med 'falsk bevidsthed'. 
Heroverfor står begrebet om en lønarbejderlivsform, der er udarbejdet i en gensidighed med (begrebet for) den kapitalistiske produktionsmåde. Lønarbejderlivsformens eksistensbetingelse er i en sådan bestemmelse den kapitalistiske produktionsmåde selv, og livsformen er dermed betinget af kapitalismens overlevelse. Når arbejdere bakker op om arbejderbevægelsen forstås det således med dette perspektiv som en bestræbelse på at forbedre sine reproduktionsvilkår som lønarbejder frem for som en hensigt om at etablere et andet økonomisk system, hvor en lønarbejderlivsform principielt ingen plads har. Hermed fremstår arbejdernes praksis som rationel og ræsonnabel, selv om denne kamp aldrig fundamentalt truer kapitalismen, men reelt kommer til at konsolidere den.

Det historiske studie, indefra og nedefra, var nødvendigt for at få indblik i den kontinuitet, der gør sig gældende i grænsedragningerne (i konstant skiftende klædedragt). Det teoretiske arbejde omkring monopoliseringens inkluderende (med anerkendelse af et system af grænsedragninger) og ekskluderende (med anerkendelse af konkrete afgrænsede arbejdsområder) side hjælper til at se, hvordan enhedsdannelsen og differentieringen er to sider af samme sag, begge nødvendige for at arbejderne har et brugbart middel til at få indflydelse på de betingelser, de eksisterer på.

På et helt fundamentalt plan skal der imidlertid tænkes endnu et element ind i figuren: selve det at monopolisere skal være anerkendt som middel. Og det er ikke bare arbejdsgiverne, der er centrale her, det er også samfundet som sådan staten om man vil - der her bliver afgørende. Og det er da også, hvad der empirisk kan konstateres i slutningen af 1800-tallet. At man - som svar på det påtrængende 'arbejderspørgsmål' - fra statens side etablerer vilkårene for at forhandle og indgå aftaler; og skrider ind og sætter sin vilje igennem, hvis det skulle være nødvendigt.

Hermed er det relevant igen at vende sig mod spørgsmålet, om der kan konstateres et samfundsomvæltende potentiale i arbejderbefolkningen? Nej, dette potentiale er der ikke, fordi truslen forsvinder, lige så snart reproduktionsbetingelserne bliver opfyldt - og hvis ikke arbejdsgiverne kan sørge for det (på det niveau og i den form den historiske kontekst måtte give), så skal staten nok garantere det. Hermed bliver arbejderne til medspillere i det kapitalistiske system. De kommer til at konsolidere systemet - i nye, mere lønarbejdervenlige former - frem for at true det. En meget væsentlig pointe er imidlertid, at den trussel, de repræsenterer i kraft af deres potentielle venden sig mod samfundet, er et afgørende middel i denne kamp for bedre betingelser. Sat på spidsen får således parolen om samfundsomvæltning (eller, om man vil, den mere milde udgave: samfundsreform) ikke en funktion som mål (som det ellers er nedfældet i partiprogrammerne), men som et middel i lønarbejdernes kamp for bedre vilkår. 


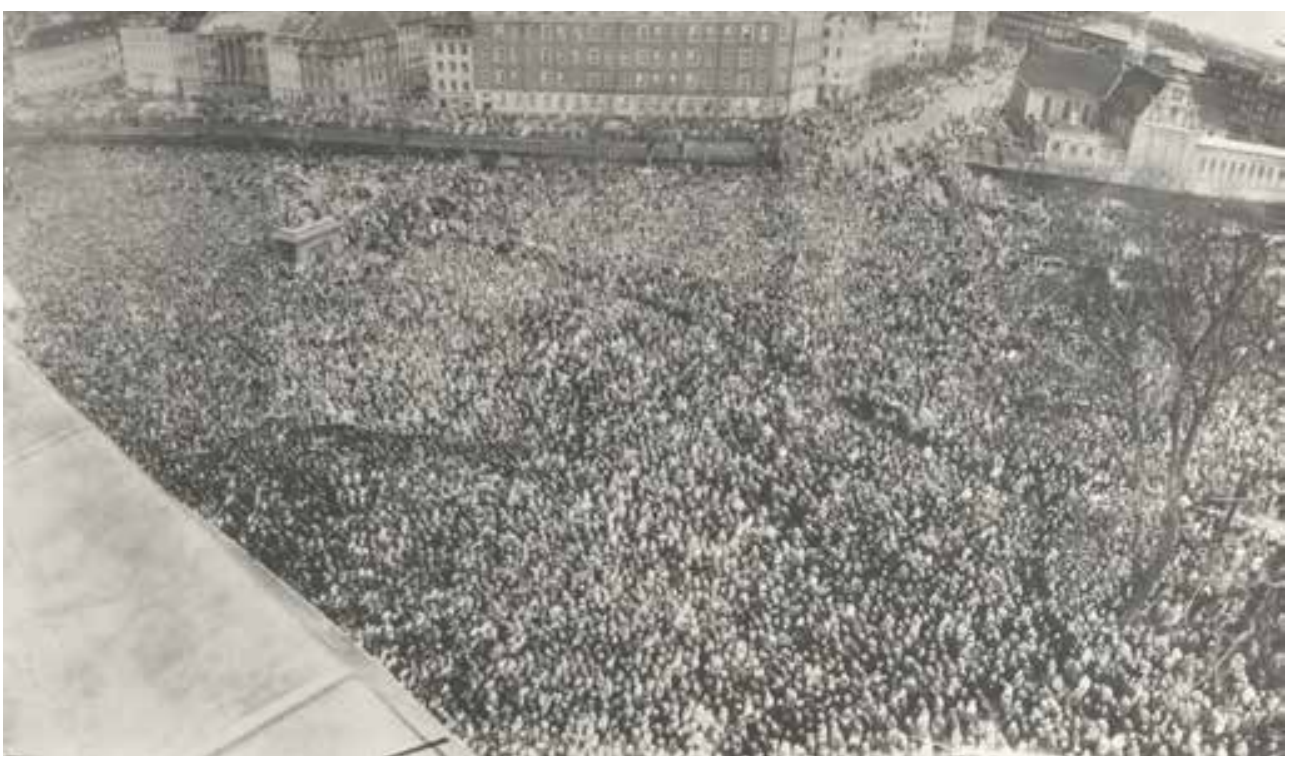

Sammenhængen mellem arbejdernes sociale og materielle vilkår og potentialet i forhold til at mobilisere dem i en konfrontatorisk bevægelse bekræftes i en dansk sammenhæng i det turbulente år 1956. Flere års manglende held med for alvor at forbedre levevilkårene samt den socialdemokratiske regerings ophøjelse af et af arbejderne forkastet mæglingsforslag til lov ved forårets overenskomstforhandlinger fører til nærmest revolutionære tilstande. Disse er ledet af kommunistiske tillidsfolk og politikere, der nyder bred opbakning fra utilfredse arbejdere. At det ikke er den kommunistiske verdensbevægelse som sådan - men snarere et effektivt pres på forbedring af levevilkårene - der er støtte til, bliver imidlertid tydeligt sidst på efteråret, da Sovjetunionen nedkæmper et folkeligt oprør $i$ Ungarn og de danske kommunister fuldstændig mister deres opbakning. Foto: ABA.

\section{I en strategisk nøglerolle}

Det historiske studie viser altså, at en fundamental differentiering har været integreret i arbejderkulturen fra dens fødsel og gennem dens modningsperiode i årtierne omkring 1900. Differentieringen er således ikke knyttet til den individualisering, som man ellers gerne sætter op som modsætning til denne historiske periode. Samtidig - og dette træk er lige så væsentligt - har arbejderne haft mulighed for, som en enhed, at opnå politisk indflydelse på samfundsindretningen. Og denne mulighed bliver kun mere udtalt gennem det 20. århundrede. I flere omgange tales der sågar igen om det revolutionære potentiale i den brede arbejderbefolkning - fx umiddelbart efter 2. Verdenskrig samt i årene omkring 1970.

Midt i 1900-tallet karakteriserer centrale amerikanske kilder knyttet til NATO simpelthen de europæiske arbejderbefolkninger som nøglefaktoren i den vestlige verdens overlevelse - "labor has in world affairs become a key factor."22 Ræson-

22 Arbejderbevægelsens Bibliotek og Arkiv: Arbejderbevægelsens Erhvervsråd kasse 26, læg 319 Den atlantiske komite. For detaljer om NATO-konferencen, hvorfra citatet stammer, se Nielsen 2004, s. 93-106. 


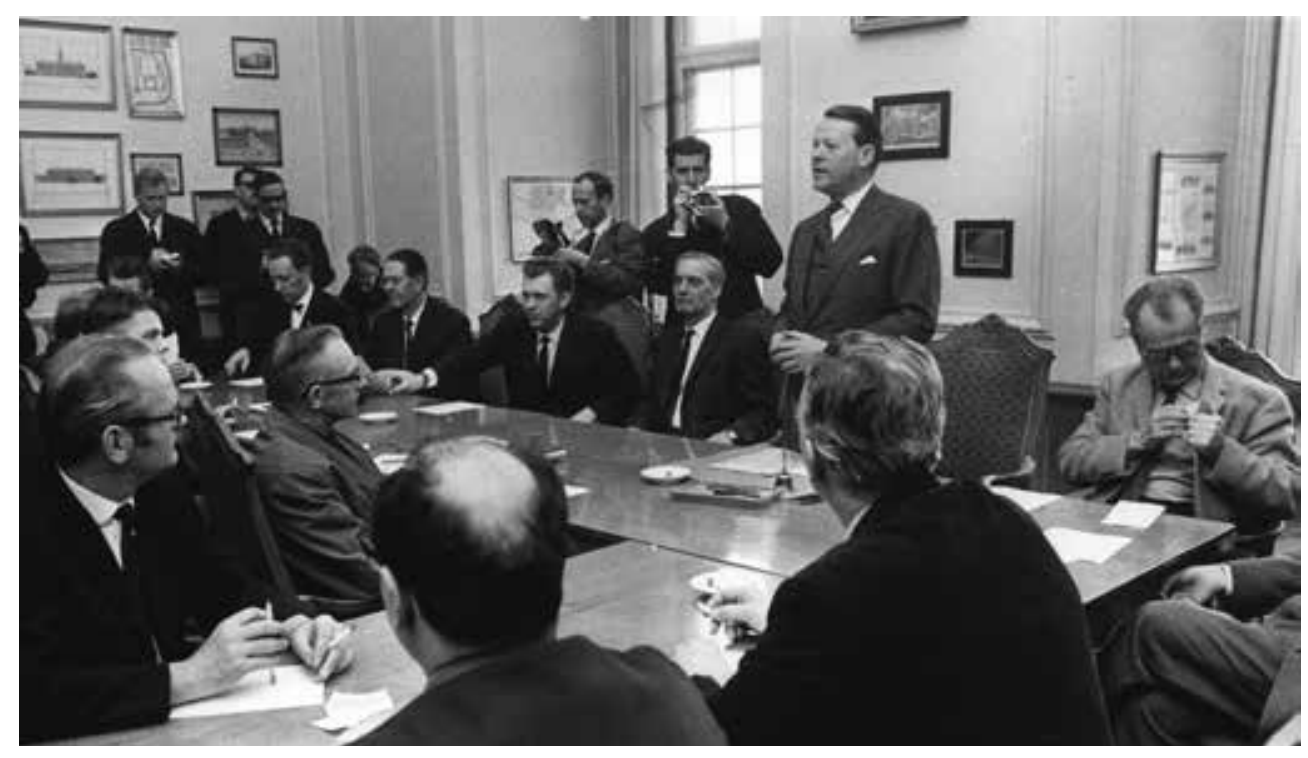

Gennem hovedparten af det 20. århundrede har lønarbejdere en mulighed for indflydelse, der kan synes overraskende i dag. Et udtryk for dét, er den danske stats indstilling til at subsidiere en løntung industrivirksomhed som B\&W, så den overlever. Ved ikke få lejligheder er virksomheden i alvorlig krise, hvorefter den reddes med statslig indgriben. Her er vi i 1967, hvor den asiatiske konkurrence truer med at lukke værftets nybygningsafdeling. Et S/SF-udvalg - med bl.a. statsminister Krag og SF-formand Aksel Larsen - tager imod fællestillidsmændene fra de fire københavnske B\&W-arbejdspladser. Ifølge billedteksten i Land og Folk, DKPs partiavis, fremfører statsministeren, "at regeringen vil gøre alt for at bibeholde beskæftigelsen". Et karakteristisk udsagn for de keynesiansk prægede vestlige økonomier i årtierne efter 2 . verdenskrig, hvor man for alt i verden vil undgå en gentagelse af 1930ernes sociale krisetilstande, der førte til radikalisering og vækst på yderfløjene. Foto: ABA.

nementet er, at de samfundsomvæltende kræfter blandt arbejdere - indirekte og direkte støttet af den kommunistiske modpart - vil få medvind i den brede befolkning, med mindre man har held til over en bred kam at imødekomme arbejderbefolkningens krav og forventninger om bedre reproduktionsvilkår: med hensyn til arbejde, bolig, uddannelse, materiel standard og meget mere. Dét giver de moderate, samfundsmedspillende, kræfter blandt arbejdere mulighed for at fremstå som en troværdig repræsentant for brede arbejderinteresser, fordi der over hele det politiske spektrum er opbakning til bedre vilkår for den jævne befolkning. Og konkret betyder det, i en dansk sammenhæng, at Socialdemokratiet, som samlende repræsentant for den systemopretholdende del af arbejderne, opnår at få en helt overvældende indflydelse på samfundets indretning. Denne evne til at fremstå som en samlet enhed udadtil må imidlertid ikke skygge for, at differentieringen indadtil på ingen måde er blevet mindsket i forhold til billedet fra slutningen af 1800-tallet - også på andre områder end hvad angår den dybe politiske splittelse mellem socialdemokrater og kommunister (og senere andre venstrefløjspartier). 
Lad os igen tage forholdene blandt de tusinder af arbejdere på B\&W som en målestok for relationer internt blandt arbejdere. ${ }^{23}$ Det mønster, vi så i den tidlige periode, er helt uændret op igennem det 20. århundrede. Livet på værkstedsgulvet foregår i vidt omfang i eksklusive enheder. Man holder sig i det daglige - også i pauserne - til sine nærmeste kolleger, dem, man har bygget arbejdsrutiner op med gennem mange år, dem, man har forpligtelser over for, dem, man har tjenester til gode hos. Ligeledes er relationen til de nærmeste arbejdsledere, hvad enten det er sjakbajser, undermestre eller mestre, helt central for at få dagligdagen til at fungere og dermed på ingen måde alene kendetegnet ved at være et modsætningsforhold. Som den mere formelle ramme om denne heterogenitet er der de lokale, virksomhedsbaserede værkstedsklubber, hvoraf der midt i århundredet er mere end tredive alene på værftet på Refshaleøen. ${ }^{24}$

Parallelt med livet i denne miniverden deltager B\&W-arbejderne i et stormfuldt storpolitisk spil, idet denne arbejdsplads - på linje med andre større (især) københavnske arbejdspladser - fremtræder som bastion i den generelle kamp for bedre vilkår. Der henvises uafvendeligt til en potentiel radikalisering, hvis man ikke giver arbejderne indflydelse. Oven i købet har B\&W-arbejderne en tendens til at vælge kommunistiske tillidsmænd, hvilket imidlertid ikke skal forklares med kommunisternes eksplicitte mål om at kollektivisere produktionsmidlerne, men snarere med, at kommunisterne (i modsætning til socialdemokraterne, der fra deres organisatoriske bagland er tvunget til at vise mådehold) er langt de mest effektive til at skabe bedre løn- og arbejdsvilkår - hvilket jo så på længere sigt paradoksalt nok (i forhold til kommunisternes egen revolutionære målsætning) fastholder arbejderne, bredt set, på en systembevarende kurs. ${ }^{25}$

Den samme logik er på færde på et lidt mere overordnet plan i årene omkring 1970, hvor den vestlige verden oplever en voldsom radikalisering, bl.a. med en

23 Indsigten i arbejdsforhold, omgangsformer, handlemønstre, selvforståelser, alliancer og brydninger i efterkrigsperioden er først og fremmest opnået gennem et omfattende interview- og observationsmateriale - som supplement til især protokolmateriale fra forbund, fagforeninger og værkstedsklubber. Kort før lukningen af B\&Ws skibsværft på Refshaleøen i 1996 lavede jeg over et halvt år feltarbejde med en kollega, Torkil Adsersen (se Adsersen og Nielsen 2005). Der foretoges i den forbindelse interviews - i udskrift ca. 400 sider - med arbejdere og ledelse på forskellige afdelinger af virksomheden. I 2000 og 2001 foretog jeg igen en tilsvarende række interviews med folk med forskellig tilknytning til B\&W, nu med øget fokus på de fagpolitiske forhold og ideologiske kampe.

24 De umådelig mange fagligheder, der er repræsenteret på et skibsværft, gør differentieringen meget tydelig, men det er helt afgørende at slå fast, at differentieringen ikke finder sin begrundelse heri. Også ufaglærte arbejdspladser - med en langt snævrere vifte af faglige specialiteter - opsplittes i et væld af hinanden afgrænsende arbejdsområder; simpelthen fordi den fagpolitiske situation er gunstig. På bryggeriet Tuborg opererer man eksempelvis omkring 1970 med en 'faglig' klub for såvel mandlig som kvindelig rengøring (Nielsen 1997), en opdeling, der selvsagt ikke er betinget af det arbejdsmæssige indhold.

25 For en nærmere udredning af argumenterne for denne fortolkning, se særligt Nielsen 2004, s. 256271. 
markant genopblussen af en retorik om revolutionær omvæltning. Alliancen mellem arbejdere og intellektuelle (fx studenter, der bekender sig til de nye venstrefløjsgrupperinger, der er dannet med en eksplicit afstandtagen til en stadig mere kompromitteret, sovjetbunden kommunisme) synes at bygge på forskellige målsætninger: Da arbejderne - i Danmark og andre steder bl.a. efter et stort antal såkaldt 'vilde' (dvs. ikke organisationsgodkendte) strejker - får gennemført nogle af deres krav, åbenbarer den latente trussel over for samfundet sig atter en gang som et middel, frem for som et mål. ${ }^{26}$

\section{Fra nøgleposition til glemsel}

Som jeg var inde på indledningsvist, har arbejderbevægelsen gennem de seneste årtier bevæget sig fra en position, hvor den i meget høj grad kunne sætte den samfundsmæssige dagsorden, til at befinde sig helt ude i periferien. I dag falder ordet 'arbejder' simpelthen forkert i munden - for slet ikke at tale om 'arbejderklasse'; i stedet bruges termer som 'medarbejdere', 'personale'og 'ansatte'. Pointen her er imidlertid, at denne fundamentale forandring ikke primært skal finde sin begrundelse i en slags vilkårlig øget individualisme eller i tab af arbejdspladser for lønarbejdere. Individualisme og kulturel heterogenitet er - som vi har set - på ingen måde ny, og trods al snak om vidensamfund er der fortsat mængder af arbejde, der i store træk er defineret på forhånd. Den store forskel fra før til nu er, at trusselsbilledet er helt forandret. Østblokkens sammenbrud fjernede fuldstændig den klangbund, som krav fra arbejderside tidligere (i meget forskellige udformninger) havde haft - med voldsomme følger for fagforeningernes evne til at fastholde betingelserne for lønarbejderne. Den taleposition, der tidligere knyttede sig til det at være 'arbejder' - med et underforstået potentiale til at indgå i en større mobilisering - er i dag næsten faldet bort. I denne bevægelse er monopolisering, som jeg her har argumenteret for kan ses som en grundbetingelse i et lønarbejderliv, kommet i voldsom modvind. Muligheden for at fremstå som et eksklusivt monopol med en særlig forhandlingsret og adgang til bestemte afgrænsede arbejdsområder udfordres af krav om åben adgang for et bredere udbud af arbejdere og adgang for konkurrerende forhandlingsformer, hvis ikke ligefrem alles ret til at tage et arbejde og selv forhandle betingelserne.

Monopoliseringens fundament er evnen til grænsedragning, og det kan se ud til, at den evne har været betinget af muligheden for gennem mobilisering at udgøre en samfundsmæssig trussel. Så, ligesom Berlinmuren faldt, da den storpolitiske storm fejede hen over Europa - og fjernede en væsentlig del af trusselspotentialet - er grænserne mellem fag, mellem kompetence- og ansvarsområder 


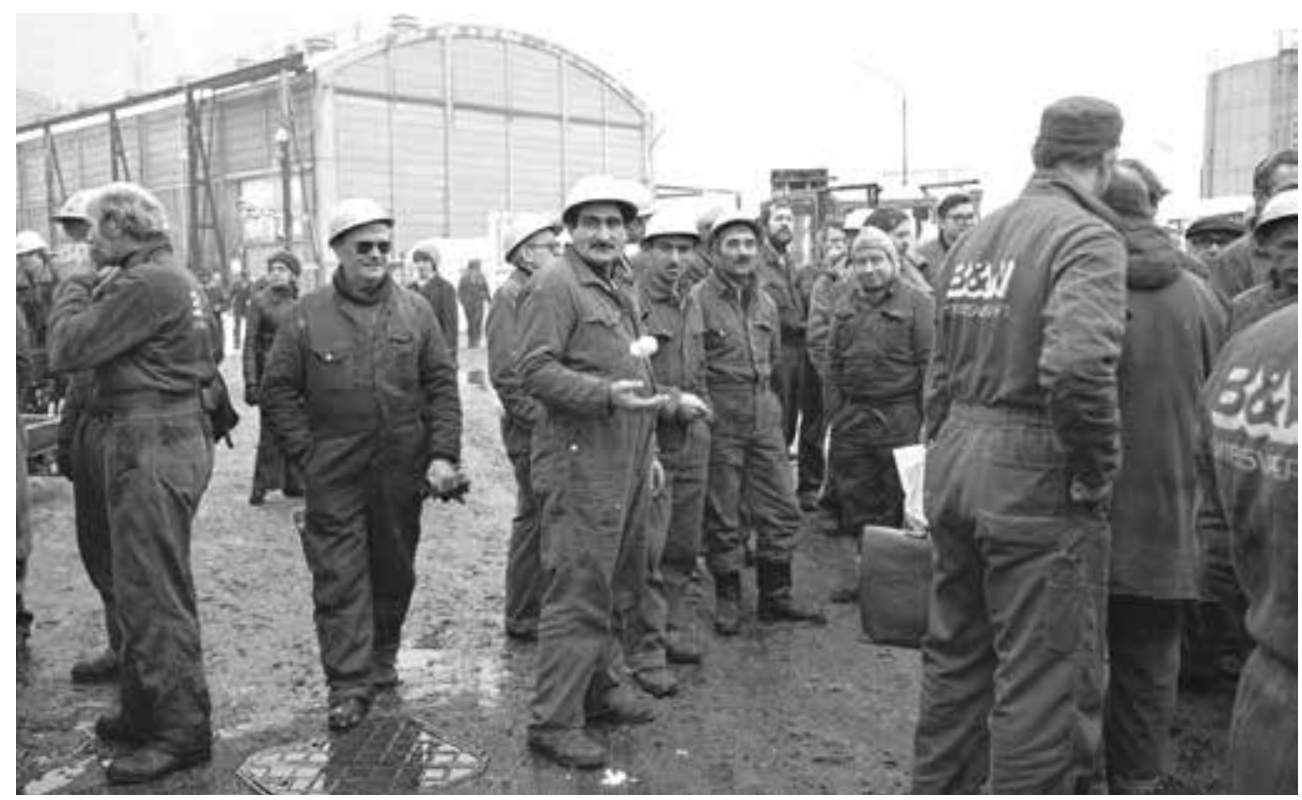

I 1969 (så vidt det kan konstateres) modtager B\&Ws skibsværft de første 'fremmedarbejdere', som det hedder i datidens sprogbrug. Arbejdernes blad Fællesklubnyt fortæller dette år, at jugoslaver er modtaget med pomp og pragt i lufthavnen, og virksomhedsbladet Intern kommunikation (1969, nr. 15), at man har modtaget et antal spanske stålarbejdere. At dømme efter interviews foretaget med B\&W-arbejdere i 1996 gav tilstedeværelsen af udenlandske arbejdere ikke anledning til nævneværdige problemer, hvilket formentlig hænger sammen med, at udenlandske arbejdere i de første årtier indoptoges fuldstændig i det eksisterende organisatoriske system; de oplevedes ikke som en trussel. Som én formulerede det: "Dem, der ikke var decideret troende, de blandede sig med os andre, ik'". Det er en meget karakteristisk forskel til i dag, hvor fagforeningernes indflydelse er mindsket og dermed deres mulighed for at sætte betingelserne for den udenlandske arbejdskraft - der samtidig har langt nemmere adgang til det danske arbejdsmarked i kraft af de åbne grænser inden for EU. Ansættelse af udenlandsk arbejdskraft foregår i dag i mange tilfælde uden for gældende overenskomster på særlige - ringere - betingelser og kommer dermed til at true selve fundamentet for at fastholde opnåede løn- og arbejdsvilkår og på længere sigt indflydelsen på, hvordan disse lægges fast. Foto: B\&W, MAN Diesel.

og mellem arbejde og fritid under nedbrydning; jf. den populære vending om 'det grænseløse arbejde'. Overalt kræves fleksibilitet og omstillingsparathed - i sin yderste konsekvens selve modsætningen til monopolisering. Og efter at mange gennem 1990'erne nærmest besang denne udvikling som en bevægelse mod 'udviklende' (sågar 'godt') arbejde, ${ }^{27}$ er såvel fagbevægelsen som arbejdslivsforskere siden blevet opmærksom på, hvordan sådanne krav lige så vel kan udmønte sig i fx alvorlige former for stress. Og det er vel ikke så mærkeligt: Hvis monopolisering er det nødvendige middel i en livsdygtig praksis som lønarbejder - hvor man ikke lever af at konstant nytænkning (og til gengæld også får en begrænset

27 Se fx Helge Hvid: Det gode arbejde, 1990. For en analyse af disse tendenser, se Nielsen 2004, s. 340-344. 
løn) - kan det ikke nytte at fjerne dens forudsætning: grænsedragningen med sin nødvendige sameksistens af inklusion og eksklusion.

Det historiske studie nedefra og indefra kunne vise arbejderkulturen i sin kompleksitet og i en sammenhæng med et teoretisk udredningsarbejde blotlægge, hvordan den vedvarende sameksistens af enheds- og differentieringstræk var et udtryk for en nødvendig betingelse for overlevelse - frem for at være et udtryk for en endnu ikke fuldbyrdet livsmåde. Denne history from below anskueliggjorde arbejdernes perspektiv i deres praksis. Det historiske studie viste imidlertid også, at det er nødvendigt at se dette billede i et større perspektiv - oppefra og udefra. Fra fødslen i 1870'erne over modningen og væksten i løbet af 1900-tallet var der fra statslig side - nationalt som internationalt - enighed om at anerkende lønarbejdere som en enhed med stor indflydelse. Situationen i dag er mere broget. Selv om samfundsdebattører især efter finanskrisen taler om, at vi fortsat lever i et klassesamfund, og der af og til drages paralleller mellem de voldsomme spændinger i flere af nutidens europæiske middelhavslande og den sociale uro i 1930'erne, så synes den referenceramme og diskursive kontekst, som de aktuelle sociale spændinger kan italesættes i forhold til, at være grundlæggende anderledes end tidligere. Truslen fra 'arbejderklassens' mobilisering er afløst en mere diffus påpegning af risikoen for social uro og opløsning. Fremtiden må vise, om og i givet fald hvordan, denne udfordring får en mere fast politisk og ideologisk form, men foreløbig er det karakteristisk, at et lønarbejderperspektiv med klare grænsedragninger i forhold til rettigheder og pligter på arbejdsmarkedet ikke på samme måde som tidligere anerkendes som en særlig subjektivitet, der skal vises specielle hensyn. Det er næppe sandsynligt, at vi på den baggrund står ved lønarbejderkulturens endeligt - af den simple grund, at lønarbejde er en integreret del af produktionslivet - men det ser ud til at blive under helt ændrede betingelser og i nye former. ${ }^{28}$

\section{Litteraturliste}

Adsersen, Torkil og Niels Jul Nielsen 2005: Sjak, mestre og skibsbyggeri. Arbejdsliv og dagligdag på B\&W 1945-1996. København.

Christensen, Erik 1978: Konflikter mellem faglærte og ufaglærte arbejdere. Ålborg.

Christiansen, Niels Finn 1997: ”Solidaritetens historie”. Dansk Sociologi, nr. 1.

28 De gennemgribende forandringer i vilkårene for lønarbejdere, der har fundet sted gennem de seneste årtier, bliver udforsket $i$ et delprojekt under det fireårige forskningsprojekt Livsformernes neokulturation under statssystemets og verdensøkonomiens forandring. Projektet, der er støttet af Velux-fonden, er forankret ved Afdeling for Etnologi, Saxo-instituttet, Københavns Universitet, og løber i perioden 2013-2016. 
Erichsen, Bjørn 1977: Om arbejderbevægelsen. En introduktionsbog til dansk arbejderbevægelses historie. Hans Reitzel.

Gray, Robert Q. 1976: The Labour Aristocracy in Victorian Edinburgh. Oxford.

Goldthorpe, John (et.al.) 1969: The Affluent Worker in the Class Structure. Cambridge.

Hvid, Helga 1990: Det gode arbejde.

Højrup, Thomas 1996: Omkring livsformsteoriens udvikling. Museum Tusculanum.

Lorentzen, Daniel og Johannes Kjærbøl 1925: Typer og tidsbilleder fra de københavnske skibsværfter, udgivet af skibssmedeforeningen $i$ København i tilslutning til dennes 30 aars stiftelsesdag den 7. april 1925. København.

Lüdtke, Alf 1986: "Cash, Coffee-Breaks, Horseplay: Eigensinn and Politics among Factory Workers in Germany circa 1900”. Hanagan, Michael og Charles Stephenson: Confrontation, Class Consciousness, and the Labor Process. USA.

Horgby, Björn 1993: Egensinne och Skötsamhet. Arbetarkulturen i Norrköping 1850-1940. Stockholm.

Joyce, Patrick 1994: Democratic Subjects. The Self and the Social in NineteenthCentury England. Cambridge University Press.

Jones, Gareth Stedman 1983: Languages of Class. Cambridge University Press.

Nielsen, Niels Jul 1997: Tuborg. Arbejdsliv og dagligdag 1955-95. København.

Nielsen, Niels Jul 2002: Virksomhed og arbejderliv. Bånd, brudflader og bevidsthed på B\&W 1850-1920. Museum Tusculanum.

Nielsen, Niels Jul 2004: Mellem storpolitik og værkstedsgulv. Den danske arbejder - før, under og efter Den kolde krig. Museum Tusculanum.

Pedersen, Jørgen 1930: Arbejdslønnen i Danmark under skiftende Konjunkturer i Perioden ca. 1850-1913. København.

Aviser og utrykt kildemateriale, der omtales i referencerne, er nøjere omtalt i forfatterens værker. 


\section{The worker between \\ practice and ideology: 1850-2000}

Labour culture and the labour movement have previously been prominent fields of research. On the one hand, this had to do with the profound societal influence of the labour movement; on the other hand, it had to do with the fact that many scholars regarded a self-conscious labour class as a means to balance capitalism's negative aspects, if not simply to overcome them. Based upon this background, the author argues that the common worker has hitherto not been satisfactorily understood as a subject of cultural history. Using detailed investigations amongst workers on the workshop floor at Denmark's largest enterprise in the period from 1850 to 2000, the author emphasises how complex and diverse the everyday working life of industrialism actually was - and hence, also the relations between workers as well as towards employers and society as a whole. This bottomup analysis is linked to a top-down perspective; here, the author argues that, as seen from the overall perspective of the state, the labour population - with varying intensity - played a very strong strategic role from around 1870 to 1990. Simply stated, consideration for the well-being of the labour population was understood as a precondition for societal cohesion.

In theoretical terms, the author draws upon the structural state-form and lifemode analysis, where the idea of a 'wage-earner' life-mode is understood in its reciprocal relationship to the capitalist mode of production and, hence, not as a potential means to overcome capitalism. With this background, the labour movement's alleged objective to overcome capitalism - whether through revolution or long-term reforms - is instead analysed as an effectual means in the movement's struggles. The argument is as follows: the threat of societal transformation, which occurred over a number of decades - not least of all during the Cold War's polarisation of capitalism and communism - led to significant attention being paid to workers' claims of improving life conditions. Accordingly, the changed world order that followed the end of the Cold War is seen as a main reason for why concepts such as 'worker' or 'labourer' are infrequently used today, and for why the labour movement has experienced a severe debilitation in recent years. 